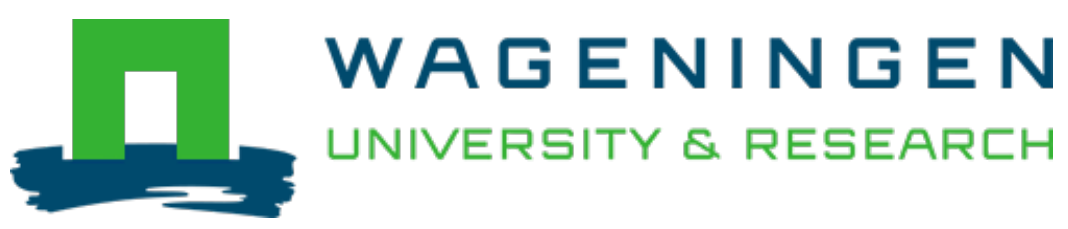

\title{
Managing internationally mobile bodies in a world on hold: Migration, tourism and biological citizenship in the context of COVID-19
}

Managing internationally mobile bodies in a world on hold: Migration, tourism and biological citizenship in the context of COVID-19

Ormond, M.E.

https://doi.org/10.1007/978-3-030-70179-6 15

This article is made publicly available in the institutional repository of Wageningen University and Research, under the terms of article $25 \mathrm{fa}$ of the Dutch Copyright Act, also known as the Amendment Taverne. This has been done with explicit consent by the author.

Article 25 fa states that the author of a short scientific work funded either wholly or partially by Dutch public funds is entitled to make that work publicly available for no consideration following a reasonable period of time after the work was first published, provided that clear reference is made to the source of the first publication of the work.

This publication is distributed under The Association of Universities in the Netherlands (VSNU) 'Article $25 \mathrm{fa}$ implementation' project. In this project research outputs of researchers employed by Dutch Universities that comply with the legal requirements of Article 25fa of the Dutch Copyright Act are distributed online and free of cost or other barriers in institutional repositories. Research outputs are distributed six months after their first online publication in the original published version and with proper attribution to the source of the original publication.

You are permitted to download and use the publication for personal purposes. All rights remain with the author(s) and / or copyright owner(s) of this work. Any use of the publication or parts of it other than authorised under article $25 \mathrm{fa}$ of the Dutch Copyright act is prohibited. Wageningen University \& Research and the author(s) of this publication shall not be held responsible or liable for any damages resulting from your (re)use of this publication.

For questions regarding the public availability of this article please contact openscience.library@,wur.nl 


\title{
Chapter 15 \\ Managing Internationally Mobile Bodies in a World on Hold: Migration, Tourism, and Biological Citizenship in the Context of COVID-19
}

\author{
Meghann Ormond
}

\section{Flows and Frictions of Disease}

Health geographers like me who study international medical travel-where people cross international borders for medical treatment not (perceived as) accessible in their regular countries of residence-have focused largely on internationally mobile patients with non-communicable diseases and ailments, as well as the diverse commercial and governmental bodies worldwide that welcome them as lucrative, nonthreatening, short-term care consumers ('medical tourists'). Such international mobility can be interpreted as a manifestation of transnational 'biological citizenship' (Rose and Novas 2004), where the biological functioning of one's body becomes increasingly central to one's individual and collective identities, generating novel spatio-relational configurations of care demands, resources, and economies that transcend the confines of a single nation-state (Ormond and Kaspar 2018). By contrast, the configurations of care and protection forming around the 'biological citizenship' of people (potentially) with communicable diseases manifest very differently, especially when borders are involved. For centuries, authorities of polities — cities in earlier times and, in modern times, also nation-states-have deployed disease-control strategies that entail monitoring people travelling into their territories, their points of departure, and the nature of their (human and more-than-human) encounters along the way for (detectable symptoms of) communicable diseases classified over time as public health threats, eventually isolating those (potentially) infected in quarantine, barring their entry or deporting them. These attempts at rendering the otherwise 'invisible enemies' of contagion visible, controllable, and expungable have relied on exclusionary bordering practices, such as the drawing of

\footnotetext{
M. Ormond $(\bowtie)$

Cultural Geography Group, Environmental Sciences Department, Wageningen University, Wageningen, The Netherlands

e-mail: meghann.ormond@wur.nl
} 
sanitary cordons to isolate and protect inhabitants' health and the placing of movement restrictions on specific mobile populations suspected to be more prone to carrying communicable disease from one polity to another (Tognotti 2013). The contrast between mobile bodies framed-whether individually or collectively-as either biologically non-threatening or threatening and the diverse bordering practices enacted in response to them reflects the highly conditional nature of hospitality to and protection of vulnerable Others extended by nation-state authorities, whose legitimacy is in part predicated on protecting and caring for those 'legitimately' residing within their national borders.

The novelty and severity of COVID-19 and the ease with which it is presently understood to be transmitted led to the rapid imposition by national governments of far-reaching, unprecedented international travel restrictions in the first half of 2020 throughout the world. Such restrictions meant that the 'biological citizenship' from which paying patients with non-threatening non-communicable conditions had previously benefited in order to move across borders for treatment had been trumped, from one day to the next, by the potential threat of their bodies—of every body, with extraordinarily limited exception-being exposed to and becoming vectors for the international spread of COVID-19. Indeed, national governments around the world seeking to stem the growth of COVID-19 were forced to quickly scramble to establish 'a new matrix to distinguish risky and unnecessary mobilities from those considered necessary and legitimate' (Scheel 2020) based on little more than a tenuous grasp of COVID-19's functioning. It is on these reactive 'scramblings' by national governments to distinguish between 'essential'/'legitimate' and 'nonessential'/'illegitimate' international mobilities in the first half of 2020 and the quandaries they encountered in drawing such distinctions that I wish to focus the remainder of this brief chapter.

\section{Bubbles, Air Bridges, and Tourist Corridors}

Despite globalization, modern nation-states largely remain containers for their inhabitants' health and welfare needs. Therefore, each national government during the pandemic has been responsible for developing its own approach to COVID-19's containment. While national strategies for the internal management of the pandemic evidenced significant degrees of diversity (e.g. the differences between the Netherland's 'intelligent lockdown', Sweden's 'lax approach', and China's 'authoritarian approach'), every national government throughout the world opted to introduce some form of restriction on international mobility to contain the spread of COVID-19. Most governments around the world rapidly closed borders to all 'nonessential' international mobility (e.g. all forms of tourism and most forms of migration), creating novel challenges. Many national borders, over decades and throughout much of the world, for instance, had been so extensively worn down or fragmented in order to facilitate supra-national regional and global 'free market' flows of people, goods, and services that some national governments-like many of the 
Schengen Treaty signatories that had not closed their borders since the 1970s-suddenly had to reinvest national physical borders with separating and closing functions once again on a large scale.

Yet, while national governments rushed to snap borders shut, many quickly came to recognize the dire economic and social challenges posed by the sudden immobilization of the international flows of people, goods, and services on which their populations had come to heavily rely. Tourism, for example, is vital to many countries' economies, with tourism revenue accounting for $10 \%$ of global GDP and employment (WTTC 2020). The once-bustling hotels, shops, and thoroughfares emptied by COVID-19 lockdowns revealed at once the economic significance of the travel and tourism sector for destinations and the extraordinary precarity of the small businesses and low-wage labour on which the sector relies in fluctuating geopolitical times. Consequently, governments were desperate to develop lockdown exit strategies to allow source and receiving countries to ease or lift travel restrictions as quickly as possible. European Union (EU) member-states, for instance, frantic to 'save the summer', entered into bi- and multilateral pacts to set up 'tourist corridors', 'bubbles', and 'air bridges' between EU countries that need not share physical borders but, instead, must demonstrate declining rates of contagion (indeed, even 'COVID-19 immunity passports' were mooted) and enforce hygienic strategies for keeping destinations clean and safe (BBC 2020). While these bordering practices may not be especially novel (consider, e.g. bilateral tourist corridor pacts between socialist countries during the Cold War (Kaspar 1981)), the adjustments to different countries' legal, infrastructure, and technological capabilities to enable contact tracing in these newly established zones are novel (Shachar 2020). COVID-19's threat of catastrophic economic effects on international tourismdependent national economies, hence, has led to significant scrambling by governments to rapidly de-territorialize and re-territorialize supra-national economic regions and zones based not only on their ever-changing grasp of the elusive nature of COVID-19's communicability (e.g. the potential to acquire immunity and the length of time one might be immune) and accessibility of technology but also on their populaces' biological conditions disciplined by different national variants of 'lockdown' policing and governmentality.

At the same time, it is worth paying attention to the exceptions that emerged at a time when uniform application of restrictions on all 'non-essential' international mobility based on prospective travellers' countries of residence appeared to be the norm. While national governments gradually began to open their borders up in mid-2020 to international mass tourists from specific countries considered sufficiently 'low risk', certain categories of people whose biological conditions and financial dealings qualified their international mobility as 'legitimate' (read 'lucrative')—like 'medical tourists' and business travellers-were able to flout travel restrictions for the masses. Thailand, for instance, rapidly restored entry to both of these niche tourism categories while only partially lifting restrictions on the far larger volumes of regular leisure-seeking tourists (Reuters 2020). Such exceptionalism offers useful perspective on how embodied 'risk' is imagined, evolves, and gets differentially attributed and practised by national governments engaging in 
crunch-time calculus of 'the greater good', where public health interests are weighed up against diverse and influential economic interests.

\section{Valuing Migrants in a World on Hold}

The suddenness of national governments' lockdown decisions around the world caught many internationally mobile people unprepared. While hundreds of thousands of international tourists were stuck in their travel destinations, leading to costly repatriation efforts by their source country governments, hundreds of millions of international migrants, by contrast, were faced with far more dire challenges. The ease with which COVID-19 spreads posed significant threat to people with irregular status and seeking asylum in overcrowded, unhygienic housing, detention centres, camps, and informal overflow sites. The lockdowns furthermore had drastic consequences on lives both in immigrants' source and receiving countries. Legalization processes were stalled, and many immigrants-concentrated in 'essential' yet precarious, low-wage jobs with limited access to protective measures-lost their jobs. Unable to work, many were stranded in receiving countries, with little to no social safety net offered either by their passport countries' governments or by (former) employers or social systems in their receiving countries. Meanwhile, at the macro level, global remittances-valued for reducing poverty and quelling social and political discontent in lower-income countries-were expected to drop dramatically, leading source country governments around the world to appeal to their immigrant diasporas to continue sending vital funds (Semple 2020).

COVID-19 furthermore shines an important light on the long-standing link between public health fears and discrimination, with poor people, ethnic and religious minorities, and immigrants frequently targeted, scapegoated, and isolated as (potential) communicable disease vectors. Indeed, some governments, like those in the United States and Malaysia, used COVID-19 to dispose of irregular immigrants, framing them as vectors of contagion, clamping down on irregular migration, increasing deportation rates, flouting international law, and turning away asylumseekers at their borders. Not all governments resorted to the old exclusionary bordering practices, however. Some turned to more inclusive ones, temporarily reclassifying 'disposable' migrants pre-COVID-19 as 'necessary' and entitled to participate in systems from which they had previously been formally excluded. Temporary regularization campaigns in countries like Portugal and Italy, for example, enabled hundreds of thousands with irregular immigration status both to work and to access health care without fear of detention and deportation. Not only was their economic contribution to these countries' care and agricultural sectors recognized as vital to national social welfare and economic stability, but also their 'biological citizenship' was recognized. Their legal identities were transformed-albeit temporarily — on the basis of non-exclusionary public health policy that recognized 
including them within a biologically vulnerable population was safer for 'the greater good' than excluding them.

\section{Conclusion}

This chapter focused on national governments' 'scramblings' at a moment of unprecedented crisis to manage different forms of international mobility on which they have grown increasingly dependent over the last decades. In deploying Rose and Novas's (2004) concept of 'biological citizenship' — which highlights how people's biological conditions can become instrumental to their political identity and capacities for demanding recognition and receiving protection and care-as a lens through which to explore how the COVID-19 pandemic offers new perspective on age-old political dilemmas of controlling the spread of contagion and its management, I brought into focus novel spatio-relational configurations of 'biological trust' in the form of bubbles, bridges, and corridors; biological risk loopholes; and biologically inclusive immigrant regularization policies. In a time where a 'new normal' future seems inevitable, with COVID-19 and the threat of other new viruses looming large, it is key to develop lines of research that explore what governmental actors have learned, and continue to learn, about bordering, distancing and segregating bodies from their national, bilateral and multilateral 'scramblings' to respond to the dramatically disorientating dilemmas induced by COVID-19's emergence. Given many national and local receiving contexts' seemingly newfound awareness of their extraordinary dependence on international tourists and migrants, it is likewise urgent to pay attention to the discourses, techniques, and technologies through which tourists and migrants' shifting individual biological conditions are being, and will in the future be, perceived, measured, reported, and scrutinized, as well as the ways in which such data will circulate, within and across borders to facilitate or inhibit increasingly personalized international mobility. It will be vital to make increasingly visible the ways in which our biological identities articulate with our political identities in an ever-more globalized world.

\section{References}

BBC. (2020, April 29). Coronavirus: Germany dashes tourism sector's hopes on lockdown. $B B C$. Retrieved September 15, 2020, from https://www.bbc.com/news/ world-europe-52470019? fbclid=IwAR01 LLwwJOgaNAddO4weIuC1iyb0fShLldC9 ryf0-Mh1IqyhgpDWBwSzC-o.

Kaspar, J. (1981). Leisure, recreation and tourism in socialist countries. International Journal of Tourism Management, 2(4), 224-232.

Ormond, M., \& Kaspar, H. (2018). South-south medical tourism. In E. Fiddian-Qasmiyeh \& P. Daley (Eds.), Routledge handbook of south-south relations (pp. 397-405). London: Routledge. 
Reuters. (2020, July 8). Thailand expects to delay plans for 'travel bubble' on virus worries. Reuters. Retrieved September 15, 2020, from https://www.reuters.com/article/us-healthcoronavirus-thailand-tourism/thailand-expects-to-delay-plans-for-travel-bubble-on-virusworries-idUSKBN2490XH.

Rose, N., \& Novas, C. (2004). Biological citizenship. In A. Ong \& S. J. Collier (Eds.), Global assemblages: Technology, politics, and ethics as anthropological problems (pp. 439-463). Hoboken, NJ: Wiley-Blackwell.

Scheel, S. (2020, March 22). The corona-pandemic: From parasitic mobility to convenient crisis. COMPAS. Retrieved September 15, 2020, from https://www.compas.ox.ac.uk/2020/ the-corona-pandemic-from-parasitic-mobility-to-convenient-crisis/.

Semple, K. (2020, April 25). Economic freeze cuts remittances, a lifeline for migrants' families. The New York Times. Retrieved September 15, 2020, from https://www.nytimes.com/2020/04/25/ world/americas/virus-migrants-mexico-remittances.html.

Shachar, A. (2020). Borders in the time of COVID-19. Ethics \& International Affairs. Retrieved September 15, 2020, from https://www.ethicsandinternationalaffairs.org/2020/ borders-in-the-time-of-covid-19/.

Tognotti, E. (2013). Lessons from the history of quarantine, from plague to influenza A. Emerging Infectious Diseases, 19(2), 254-259.

World Travel and Tourism Council (WTTC). (2020). Economic impact reports. London: Author. Retrieved September 15, 2020, from https://wttc.org/Research/Economic-Impact.

Meghann Ormond is Associate Professor in Cultural Geography at Wageningen University \& Research in the Netherlands. Her research, teaching, and societal engagement are deeply invested in and concerned with how differently mobile people's roots, rights, and vulnerabilities are recognized and included in the places they visit and in which they live. Her main research interests focus on transnational healthcare, migrants' integration, and heritage-making practices. She is the author of 40 peer-reviewed journal articles, book chapters, and books on diverse facets of transnational mobility, health, and care, and she also serves on the editorial boards of Globalization \& Health and Current Issues in Tourism. 